\title{
Impact of subglacial hydrology on the release of water from temporary storage in an Alpine glacier
}

\author{
Nick J. RUTTER* \\ Department of Geography, University of Oxford, Mansfield Road, Oxford OX1 3TB, UK \\ E-mail: nick.rutter@aber.ac.uk
}

\begin{abstract}
Periods of storage and release of surface runoff that is routed englacially and subglacially are identified from a time series of cumulative water balance between 31 July and 11 September 1999 at Findelengletscher, Switzerland. The influence of subglacial hydrology on water routing within the glacier, and therefore on trends of water storage and release, is determined through comparisons of phase relationships between daily maxima, daily minima and diurnal ranges of borehole water levels, supraglacial runoff and proglacial discharge. Variations of water levels in 21 boreholes in the ablation zone suggest that although subglacial drainage is spatially dynamic, hydrologically efficient tunnelconduit-style drainage dominates diurnal cycles of water transfer through the glacier. Over longer periods, however, storage and release of subglacially routed water is greatly influenced by the coexistence of, and temporary interconnections between, hydrologically inefficient distributed drainage and the tunnel-conduit network. Water levels in three boreholes indicate that after water storage increases in distributed drainage, hydraulic gradients between the different drainage systems may increase sufficiently to cause connections that initiate release of water when: (1) low maximum daily surface runoff causes low water pressures in the tunnel-conduit system; or (2) reorganization within distributed drainage causes spatially localized increases in water pressure.
\end{abstract}

\section{INTRODUCTION}

Evolution and deterioration of the glacial hydrological system, in response to supraglacial runoff during the ablation season, has a critical controlling influence over rates of water flow through glacierized catchments. The spatial distribution of englacially and subglacially routed water can be highly dynamic throughout an ablation season and either increase or attenuate discharge from glacierized catchments. Consequently, routing of supraglacial runoff through a glacier has an important influence over whether a glacier exhibits an increase (storage) or decrease (release) in water balance.

Seasonal evolution is considered to occur when increasing volumes of runoff cause hydrologically inefficient, spatially distributed drainage, such as linked cavities (Kamb, 1987) or non-arborescent canals (Walder and Fowler, 1994), to be replaced as the dominant drainage type by fewer, larger and more hydrologically efficient subglacial channels such as R channels (Röthlisberger, 1972) or broad low channels (Hooke and others, 1990). Previous studies of intermediate-term water storage (Jansson and others, 2003) during the ablation season tend to focus on water balance during hydrological release events. Examples of such events are those in the early ablation season (Anderson and others, 1999; Schuler and others, 2002) that cause a rapid advance in evolution of the drainage network, or events towards the end of the ablation season in response to high-elevation rainfall (Barrett and Collins, 1997; Collins, 1998; Denner and others, 1999). Fewer studies explicitly consider water storage or water balance in the mid-ablation season after spring events (Collins, 1982a). In particular, less attention is given to the potential for oscillations in subglacial water

*Present address: Centre for Glaciology, Institute of Geography and Earth Sciences, University of Wales, Aberystwyth SY23 3DB, UK. storage (Anderson and others, 2003) that may result from coexistence of hydrologically efficient and inefficient drainage (Nienow and others, 1996a) and subglacial areas switching between drainage types (Murray and Clarke, 1995). The aim of this paper is to calculate and identify trends in water balance and periods of water storage and release during the mid-ablation season. The potential for coexistence of efficient and inefficient subglacial drainage systems is assessed using borehole water levels as a proxy for subglacial water pressures. The impact coexistence may have on storage and release of supraglacial runoff routed through the glacier is then discussed.

\section{INTERPRETATION OF SUBGLACIAL DRAINAGE USING BOREHOLES}

As subglacial drainage in temperate glaciers can be highly dynamic in spatial configuration (Nienow and others, 1996a) and capacity of channels to discharge runoff (Schuler and others, 2004), multiple in situ observations are required at a high temporal resolution (hourly or sub-hourly). Although in situ measurements of englacial and subglacial environments are possible using tunnels in bedrock beneath a glacier (Cohen and others, 2000) and tracer experiments (Fountain, 1993; Nienow and others, 1996b), borehole arrays are currently the only way of obtaining continuous hourly observations over a wide spatial area for long enough to study water-balance cycles.

Many investigators have used the assumption that water levels are a manometrical response to changes in subglacial water pressure in boreholes that are unfrozen at the glacier surface (Hodge, 1979; Iken and Bindschadler, 1986; Fountain, 1994; Murray and Clarke, 1995; Gordon and others, 1998). Using the classification of Gordon and others (2001), boreholes are either connected, where the physical properties of boreholes respond to the glacial drainage 


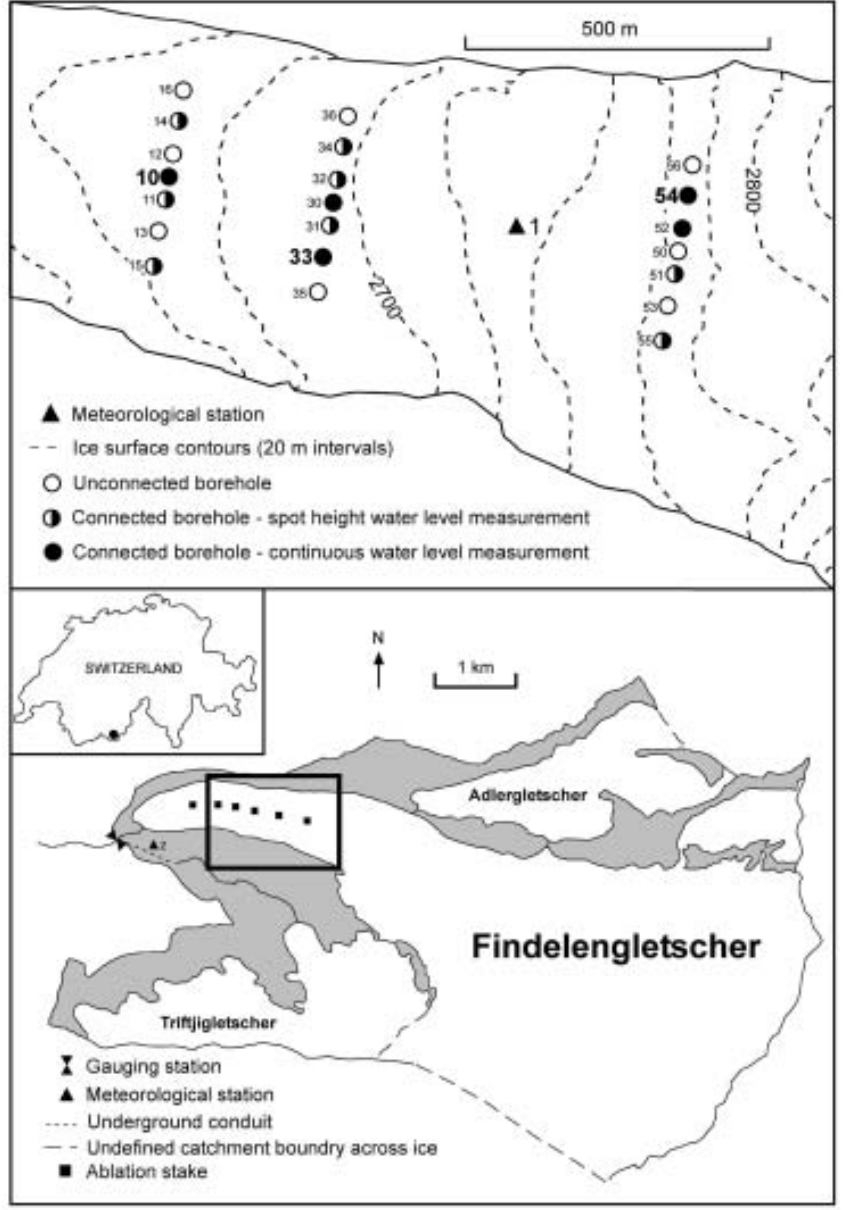

Fig. 1. Location map of Findelengletscher, showing the location of discharge gauging station, meteorological stations and boreholes drilled in 1999. Hydrological connections of boreholes with the subglacial drainage system (connected or unconnected) are indicated, as well as the measurement resolution of borehole water levels (continuous measurements using pressure transducers or manual spot height measurements).

system, or unconnected, where properties remain static. Variations in water levels of connected boreholes are dependent on both subglacial and englacial hydrological connectivity, and the permanency of these connections. Gordon and others (2001) concluded that in the absence of hydrostratigraphic profiling (Smart and Ketterling, 1997), or the use of 'hydrology units' incorporating electrical conductivity cells and turbidity sensors (Stone and Clarke, 1996), drilling records and video profiling provide the next best supporting data to verify the influence of the glacial drainage system on borehole water levels. Using these supporting data, unconnected boreholes can be subdivided into those that terminate in englacial ice, referred to as blind, and those that terminate basally but fail to respond to the drainage system, which are referred to as apparently unconnected. Connected boreholes can be subdivided into either englacially connected, basally connected or a combination of both, multiply connected. Finally, connected and unconnected boreholes subdivide into those that intersect an englacial cavity that itself is unconnected to the drainage network, referred to as complex, and boreholes that have no intersections of this kind, which are termed simple.

Even when boreholes are classified as simple and are only connected subglacially, interpretation of subglacial drainage using water pressures reflected by borehole water levels is complicated. Comparisons of absolute volumes of subglacial water flow in areas around two different boreholes are impossible to infer from water pressures. For example, high water pressures in a small channel may reflect the same discharge as low water pressures in a large channel. Comparison of borehole water levels in different areas of subglacial drainage is further complicated by the nature of the hydrological connection between the base of a borehole and the subglacial channel or cavity. When the hot-water drill reaches the glacier bed, a hydrological connection between the base of the borehole and a subglacial channel or cavity can be created through direct intersection, through a sedimentary substrate or between basal ice and bedrock. A hydrological connection may occur immediately or gradually, depending on how the hydraulic gradient, set up between the base of the borehole and the channel or cavity, interacts with the local subglacial environment. The nature of the hydrological connection can affect the diurnal maximum, minimum and range of borehole water levels. Consequently, the manner in which borehole water levels reflect subglacial water pressures surrounding the base of a borehole are site-specific. This makes direct comparison of water levels between boreholes inappropriate. Instead, comparison of variations within a borehole water-level time series with variations within another time series (supraglacial runoff, discharge or water levels in different boreholes) is necessary. Analyses of subglacial drainage in this study, therefore, compare phase relationships within these limitations between diurnal maxima, minima and ranges of hydrological inputs to, throughputs within, and outputs from, the glacial hydrological system.

\section{STUDY SITE AND METHODS}

Findelengletscher is situated in the upper Rhône basin of the Swiss Alps at $46^{\circ} 01^{\prime} \mathrm{N}, 7^{\circ} 50^{\prime} \mathrm{W}$ (Fig. 1). Hourly discharge from Findelengletcher is measured in a hydroelectric adduction gallery approximately $750 \mathrm{~m}$ from the glacier terminus during the ablation season from Julian day (JD) 145 to 297 in 1999. Measurements incorporate discharge from Triftjigletscher; however, ungauged field observations indicate discharge from Triftjigletscher is very small relative to Findelengletscher and it is considered to have a negligible impact on variations of discharge from Findelengletscher.

Hourly meteorological data are collected at two different measurement sites from JD 212 to 254 . Global radiation and precipitation data are collected at meteorological station 1, and air-temperature data are collected at meteorological station 2. Visual estimates of the elevation of the transient snow-line (TSL) are made daily. Hourly estimates of supraglacial runoff are made from these meteorological data using a temperature-index melt model (Rutter, 2002), modified from Model 3 in Hock (1999, p. 104). Hock uses two non-physically based parameters to optimize melt; however, to increase the physical basis of this model, one of the parameters uses measured rather than purely statistically optimized albedo values of snow and ice, 0.7 and 0.195 respectively (Bezinge, 1987), which are scaled by $10^{-4}$. The remaining parameter, the melt factor parameter, is optimized using proglacial discharge. It is optimized using the efficiency criterion of Nash and Sutcliffe (1970) without the use of a routing component, to avoid introducing assumptions about flow rates within englacial and subglacial 
reservoirs into future water-balance calculations. Any further increase in the efficiency criterion would require a discharge routing component. Spatial differences in melt rates over the glacier surface are reflected by separating the glacier surface into $100 \mathrm{~m}$ elevation bands rather than $30 \mathrm{~m}$ by $30 \mathrm{~m}$ gridcells. The elevation of the TSL is estimated at a daily resolution and demarcates the glacier into areas that contribute to runoff (below the TSL) and those that do not (above the TSL). Sporadic low-elevation snowfall events are therefore incorporated into calculations of runoff. Consequently, the glacier hypsometry interacts with air-temperature lapse rates to reflect changes in the intensity of meltwater runoff in each $100 \mathrm{~m}$ elevation band over the snow-free glacier surface. Runoff from rainfall is distributed over the snow-free glacier surface in a similar manner and is added to meltwater to create the total volume of runoff.

Twenty-one boreholes, drilled from the surface to the base of the glacier using high-pressure hot-water drilling techniques, are arranged in three lateral arrays of seven boreholes between 2660 and 2780 ma.s.l. (Fig. 1) and are identified using the numbering convention of Østrem and Brugman (1991). Boreholes are classified into one of three types depending on connections with the glacial hydrological network and the measurement resolution of water levels within each borehole: (1) unconnected (visual inspection of water level at or near surface); (2) connected (manual spot height measurements of water level); or (3) connected (continuous measurement of water levels at 10 min intervals). Of the five boreholes that have continuous water-level measurements, data from three of them, 10, 33 and 54 (highlighted by bold labelling in Fig. 1), are presented.

Spot height measurements of borehole water levels are made either by video profiling or by lowering a reinforced electrical conductivity probe down a borehole and detecting the water surface by a rapid increase in conductivity. Continuous measurements of borehole water levels are made using Gems TransInstrument pressure transducers across a $0-40 \mathrm{~m}$ range. Transducers are positioned at approximately $35 \mathrm{~m}$ beneath the estimated maximum diurnal water level in order to optimize the range whilst maintaining a high measurement resolution. If water levels rise above or fall below the $40 \mathrm{~m}$ range initially estimated, pressure transducers are moved up the borehole in order to prevent prolonged over-pressurization, or down the borehole to prevent missing data. Differences in transducer height relative to borehole water levels are corrected during post-processing. Despite regular daily inspections, each transducer (or cable) eventually becomes frozen to the sidewall of the borehole. Subsequently, the transducers cannot be moved within the borehole, and undergo periods where they are either out of the water or over-pressurized. As these transducers can withstand large overburden pressures, but not measure them at the same accuracy as within the designated range, data collected during known periods of over-pressurization are removed.

Boreholes did not freeze at the glacier surface throughout the measurement period. As a result, water seepage through surface ice layers into boreholes could not be prevented. Rates of intergranular flow of water through surface ice, however, are very small relative to the rates of movement in borehole water levels and are considered to have a negligible impact. All supraglacial streams, which potentially could have a much greater impact on borehole water levels, were diverted away from borehole openings to

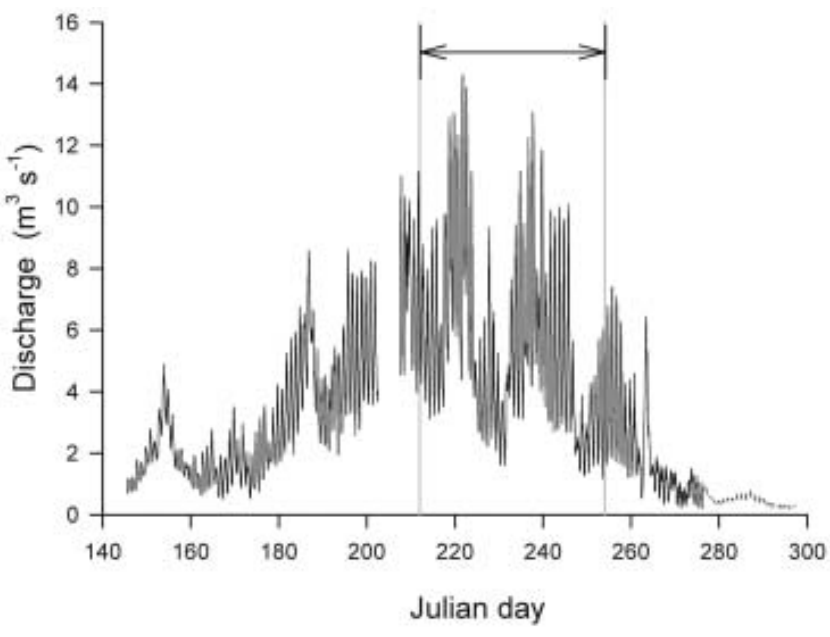

Fig. 2. Discharge of the Findelenbach (draining from Findelengletscher) during the ablation season in 1999. Arrow indicates the period when water balance and borehole water levels are assessed.

prevent any significant influx of surface water from distorting variations caused by subglacial water pressures.

Data continuity is limited, primarily due to movement of borehole water levels out of the measurement range of the pressure transducers, but also because of sporadic equipment failure. In combination with discontinuities in hydrometeorological and discharge data, only frustratingly short discrete sequences in the time series show simultaneous measurements of all variables. In an attempt to increase the amount of continuous borehole water-level data available for analysis, reconstruction of missing data has been carried out, where possible, using methods described in the Appendix.

\section{VARIATIONS IN WATER BALANCE}

Water balance is calculated during the mid-ablation season, when daily maximum discharges and diurnal ranges of discharge are around annual maxima (Fig. 2). Meteorological and glaciological data (Fig. 3a and b) are used to calculate supraglacial runoff (Fig. 3c). Discharge is then subtracted from supraglacial runoff to produce the water balance (Fig. 4a).

The accuracy of the water balance is dependent on errors associated with the calculation of its individual components. All runoff from the catchment outlined in Figure 1 is routed through the gauging station, and rock that underlies the catchment provides a predominantly impermeable surface, other than in areas of discrete jointing (Bearth, 1953). As seismic soundings suggest there are no major overdeepenings beneath the ablation area of Findelengletscher (Süsstrunk, 1959), the possibility of runoff being lost from the catchment in a groundwater aquifer or stored behind a major subglacial bedrock constriction is low. Accuracy of gauge measurements is uncertain; however, in a similar adduction-gallery-style gauging station capturing the proglacial river draining Gornergletscher in the adjoining valley, measurement accuracy has been estimated to be about $5 \%$ of true values (Collins, 1982b).

To evaluate the performance of the surface runoff model, estimates of modelled runoff are compared with measurements of glacier surface ablation made between JD 214 


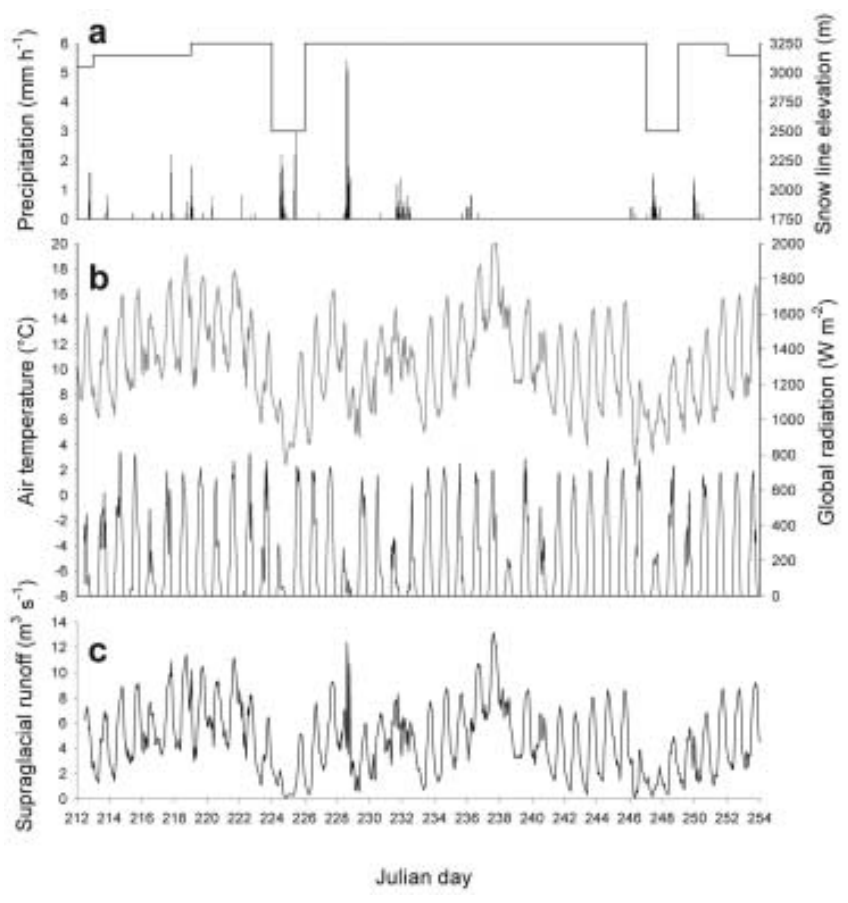

Fig. 3. (a) Hourly total precipitation (bars) and daily estimates of snow-line elevation (solid lines); (b) diurnal variation of air temperature (grey lines) and incoming solar radiation (black lines); and (c) supraglacial runoff.

and 243. Daily measurements of surface lowering are made using six ablation stakes drilled into the glacier surface in the ablation zone at roughly equidistant intervals along the fall line of the glacier (Fig. 1). Approximation of surface runoff is then calculated by extrapolating an average ablation value across the snow-free area of the glacier. Daily totals of surface runoff from ablation measurements are much more erratic than daily totals of modelled runoff or proglacial discharge (Fig. 5a). Consequently, statistical comparison is more appropriate between cumulative totals. Figure $5 \mathrm{~b}$ shows that cumulative daily totals of modelled surface runoff consistently underestimate cumulative daily totals of runoff from surface lowering after JD 220. The mean absolute percentage error between cumulative modelled runoff and cumulative runoff calculated from ablation measurements is $16.5 \%$. Uncertainty exists, however, as to whether this error is a function of inaccuracies in the model or whether daily ablation measurements at six ablation stakes accurately represent surface melt over the entire ablation area of the glacier. Consequently, although an estimate of error in modelled runoff is possible from comparison with independent measurements, it is considered inappropriate to use it to scale up underestimated modelled values. As the difference in frequency of measurements (hourly modelled runoff compared to daily measurements of ablation) required comparison through cumulative totals, it is also inappropriate to resolve an hourly absolute error for modelled runoff from absolute error of cumulative daily runoff between the two parameters.

Underestimation in modelled runoff may be caused by the exclusion of meltwater from snowmelt above the TSL. However, as the elevation of the TSL is at or near the annual maximum from JD 212 to 254, volumes of runoff from further melt-out of snow will be very low. In the model, it is assumed that water produced from snow surface melt is

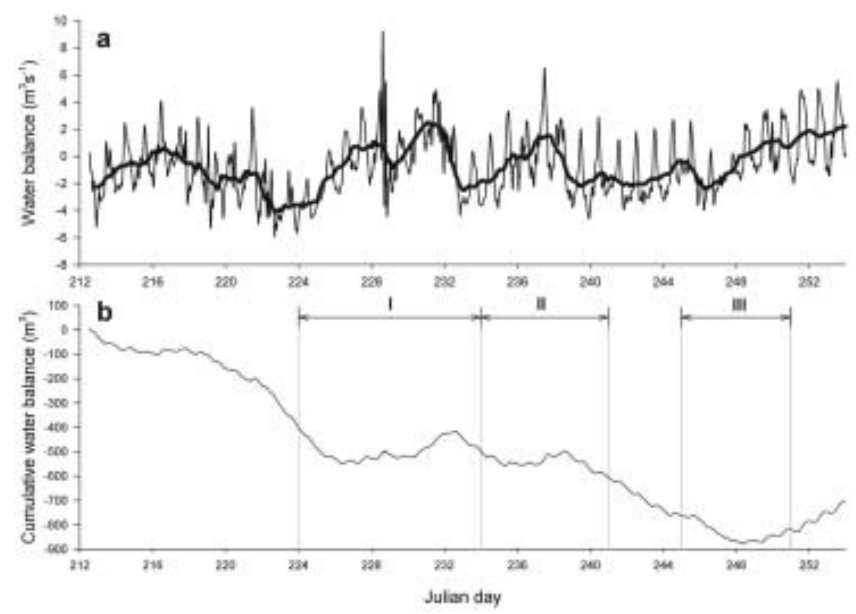

Fig. 4. (a) Water balance (thin solid line); 24 hour running average (thick solid line); (b) cumulative water balance (periods I-III refer to hydrological periods in discussion).

retained within pore spaces of unsaturated snowpacks or is refrozen. Although this may not reflect snowpacks that are at or near isothermal conditions close to the TSL, it is likely to accurately describe the majority of the accumulation zone. This is backed up by measurements at Storglaciären, Sweden, where although $44 \%$ of maximum total water storage occurs within firn and snow aquifers (Schneider, 2000 ), only $2 \%$ accounts for annual runoff from the same glacier (Schneider, 2001).

Another source of underestimation may be meltwater from aperiodic low-elevation snowfall events, which is not accounted for due to limitations of precipitation measurement equipment. The volumes of meltwater produced from such trace coverings of the ablation zone, however, are likely to be very small and have a much greater influence on modelled surface runoff by reducing rates of ice melt. This influence is incorporated into modelled results through a reduction in elevation of the TSL.

Due to these uncertainties involved in error calculation of modelled runoff, interpretation of the resulting water balance is limited to relative changes in rates of increasing and decreasing water balance within the glacial hydrological system. It cannot accurately be used to calculate changes in absolute volumes of the water balance. A 24 hour running average highlights trends in the water balance (Fig. 4a), and cumulative water balance (Fig. 4b) indicates periods of water storage (increasing cumulative water balance) and release (decreasing cumulative water balance).

\section{SPATIAL VARIATIONS IN SUBGLACIAL DRAINAGE}

Figure 1 indicates that eight boreholes are drilled into areas of the glacier bed that are hydrologically isolated from the subglacial drainage system. Using the classification of Gordon and others (2001), it is likely that all of these boreholes are apparently unconnected. In cases where there was no immediate hydrological connection between a borehole and the subglacial drainage network, the hotwater drill was left running at the base of a borehole for $60 \mathrm{~min}$. This is done to reduce the chance of sediment or debris-rich basal ice causing a premature englacial restriction to drilling, or a blind hydrological connection. Drilling records, borehole video profiling, and both spot height 

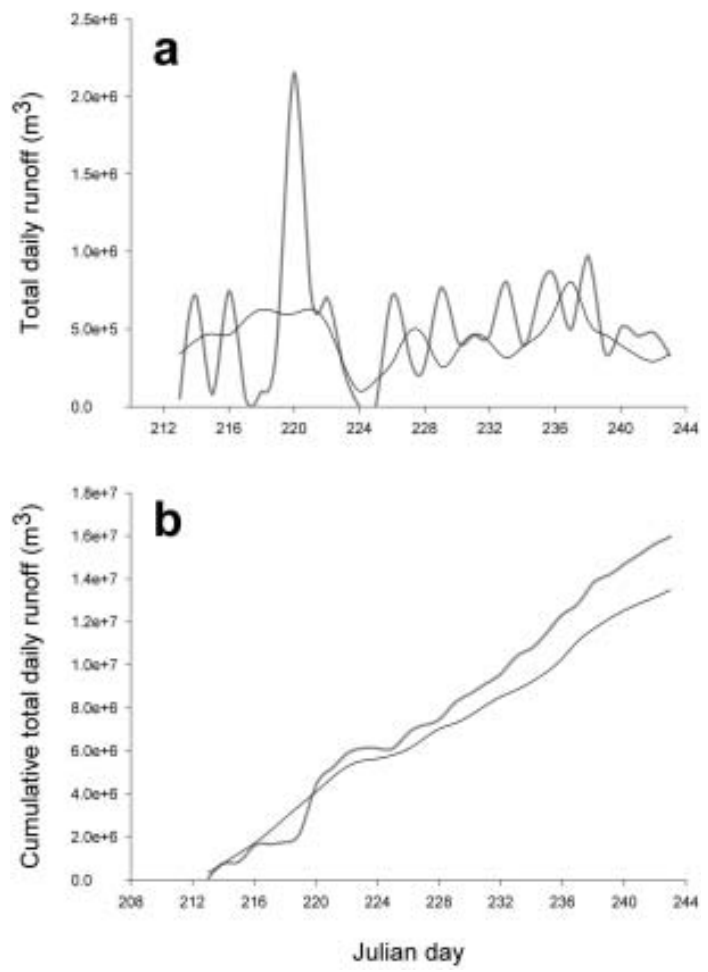

Fig. 5. (a) Total daily runoff calculated from ablation measurements (grey line) and modelled runoff (black line); (b) cumulative daily runoff from ablation measurements (grey line) and modelled runoff (black line).

(Table 1) and pressure-transducer measurements of borehole water levels indicate that three of the remaining thirteen boreholes that connected with the glacial hydrological system can be classified as complex. Of these three, borehole 51 is englacially connected, borehole 30 is subglacially connected and borehole 55 , which is located in an area of heavy crevassing on the south side of the glacier, is multiply connected. The remaining ten boreholes can be classified as simple. Of the ten boreholes with simple hydrological connections, only borehole 33 connected immediately with subglacial drainage; the remaining boreholes took 1-24 days for water levels to exhibit signs of connections with the glacial hydrological system.

Out of the five boreholes where water levels are continuously monitored, data from boreholes 30 and 52 were too discontinuous to allow spatial interpretation of variations in water balance. Water levels in boreholes 10, 33 and 54, however, provide enough data, when including short reconstructed periods of missing data, to compare concurrently with each other and the water balance. Phase relationships between these parameters are now discussed in reference to causes of storage and release in the water balance.

\section{SEASONAL DEVELOPMENT OF SUBGLACIAL DRAINAGE}

From JD 195 onwards, an increase in the capacity of the subglacial drainage network to discharge runoff is evident from associated increases in daily maxima and range of discharge (Fig. 2). This suggests that the hydrologically efficient tunnel-conduit system at Findelengletscher concentrates subglacial flow into relatively few, efficient R-channel-style conduits in a manner similar to that proposed by Iken and
Table 1. Spot height measurements of distances between water levels in boreholes and the glacier surface, in boreholes that connected temporarily or permanently with the glacial hydrological system $(\mathrm{D}=$ borehole drilled, $\mathrm{S}=$ water level at glacier surface, $\mathrm{U}$ $=$ water level unknown, $\mathrm{C}=$ borehole closed shut through ice deformation). Shaded values indicate the period water balance is calculated

\begin{tabular}{|c|c|c|c|c|c|c|c|c|}
\hline \multirow{2}{*}{$\begin{array}{l}\text { Julian } \\
\text { day }\end{array}$} & \multicolumn{8}{|c|}{ Borehole } \\
\hline & 11 & 14 & 15 & 31 & 32 & 34 & 51 & 55 \\
\hline 180 & & & & & & & $D, S$ & \\
\hline 181 & & & & & & & U & $\mathrm{D}, \mathrm{S}$ \\
\hline 183 & & & & & & & $67.5 \mathrm{~m}$ & $11.0 \mathrm{~m}$ \\
\hline 188 & & & & & $\mathrm{D}, \mathrm{S}$ & $\mathrm{D}, \mathrm{S}$ & & \\
\hline 189 & & & & & U & U & U & $U$ \\
\hline
\end{tabular}

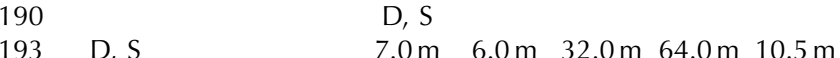

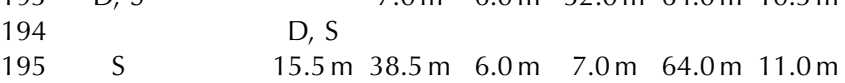

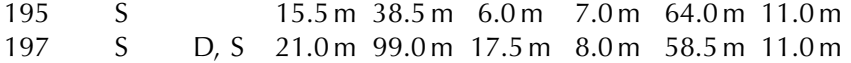

$198 \mathrm{~S} \quad \mathrm{~S} \quad 15.5 \mathrm{~m} \quad \mathrm{U}$

$\begin{array}{llllll}204 & & & 86.0 \mathrm{~m} & \text { U } & 48.0 \mathrm{~m}\end{array}$

$\begin{array}{llll}205 & \mathrm{~S} & \mathrm{~S} & 13.5 \mathrm{~m}\end{array}$

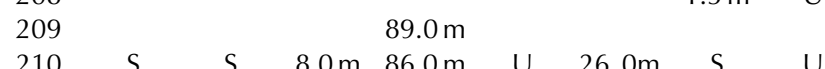

$\begin{array}{ccccccccc}210 & \mathrm{~S} & \mathrm{~S} & 8.0 \mathrm{~m} & 86.0 \mathrm{~m} & \mathrm{U} & 26.0 \mathrm{~m} & \mathrm{~S} & \mathrm{U} \\ 212 & & & & \mathrm{U} & \mathrm{U} & 17.5 \mathrm{~m} & \mathrm{~S} & \mathrm{U} \\ 217 & 1.0 \mathrm{~m} & 7.5 \mathrm{~m} & 7.0 \mathrm{~m} & \mathrm{U} & \mathrm{U} & 3.5 \mathrm{~m} & \mathrm{~S} & \mathrm{U} \\ 220 & & & & & & & \mathrm{~S} & \mathrm{U} \\ 222 & 5.0 \mathrm{~m} & 15.0 \mathrm{~m} & \mathrm{~S} & \mathrm{U} & \mathrm{S} & 6.5 \mathrm{~m} & & \\ 229 & 13.0 \mathrm{~m} & \mathrm{~S} & \mathrm{~S} & \mathrm{U} & \mathrm{S} & 2.0 \mathrm{~m} & & \\ 230 & 11.5 \mathrm{~m} & 0.5 \mathrm{~m} & 0.5 \mathrm{~m} & \mathrm{U} & \mathrm{S} & 4.0 \mathrm{~m} & & \\ 231 & & & & & & & \mathrm{~S} & \mathrm{U} \\ 237 & & & & & & & \mathrm{~S} & \mathrm{U} \\ 239 & 6.0 \mathrm{~m} & & & 32.0 \mathrm{~m} & \mathrm{~S} & 2.5 \mathrm{~m} & & \\ 243 & \mathrm{~S} & \mathrm{~S} & \mathrm{~S} & \mathrm{U} & \mathrm{S} & 2.0 \mathrm{~m} & \mathrm{~S} & \mathrm{U} \\ 259 & \mathrm{U} & \mathrm{S} & \mathrm{S} & \mathrm{U} & \mathrm{C} & \mathrm{U} & \mathrm{S} & \mathrm{U}\end{array}$

Truffer (1997). It is likely these channels will dominate variations in subglacial water pressure in the surrounding areas, as has been shown in other temperate Alpine glaciers (e.g. Haut Glacier d'Arolla, Switzerland (Hubbard and others, 1995)). The spatial and temporal variability of water levels in 21 boreholes indicated by Figure 1 and Table 1, however, suggests that despite the high efficiency of the tunnel-conduit network it continues to coexist with distributed drainage throughout the mid-ablation season. Coexistence of, and interactions between, distributed and tunnelconduit-style subglacial drainage, and their influence over storage and release of runoff, are now discussed.

\section{Release of water from temporary subglacial storage}

Three hydrological periods are identified in Figure $4 \mathrm{~b}$ where the cumulative water balance shows a change between water storage (positive gradient) and release (negative gradient). Due to the identified uncertainty in the degree of underestimation between modelled runoff and actual runoff, interpretation of this graph is limited to the sign of the gradient of cumulative water balance and the timing of a change in sign rather than either the rate of change or absolute volume.

Rapid transit of supraglacial runoff through simple and hydrologically efficient tunnel-conduit drainage to the 

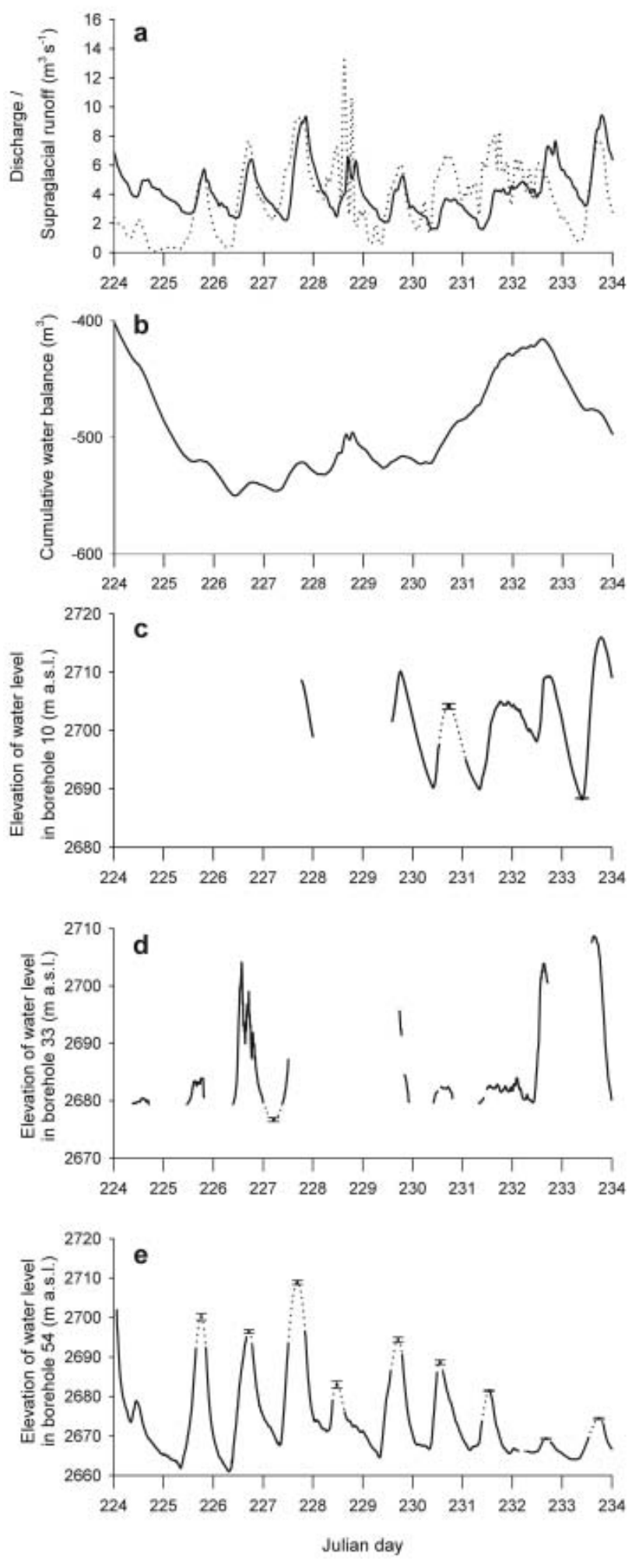

Fig. 6. (a) Surface runoff (pecked line) and proglacial discharge (solid line); (b) cumulative water balance; (c-e) water levels in boreholes 10 (c), 33 (d) and 54 (e). Estimates are made of borehole water levels during periods with missing data (pecked lines) including estimates of diurnal maximum and minimum water levels (with error bars at $99 \%$ confidence intervals).

proglacial river means that maxima and minima of proglacial discharge can be used as an analogous measure to fluxes within the tunnel-conduit system. This is possible as although $\mathrm{R}$ channels in equilibrium have an inverse relationship between water pressure and discharge, variations in water pressure over a diurnal time-scale are likely to be too rapid for the system to become equilibrated by creep closure of channel walls. This is corroborated by comparison with calculated channel closure rates of a possible $24 \%$ decrease in channel radius in 12 hours under $350 \mathrm{~m}$ of temperate glacier ice at Unteraargletscher, Switzerland (Schuler and others, 2004). As Findelengletscher is less than half that thickness (98-183 m throughout the borehole array) and as the rate of conduit closure increases as the third power of ice thickness (Anderson and others, 2003), it is unlikely the tunnel-conduit system will be equilibrated over diurnal time-scales.

In these analyses, assumptions are made that change in englacial storage is not significant over diurnal cycles and that supraglacial storage is negligible due to heavy crevassing. Comparison of daily maxima and minima of runoff and discharge are then used to describe the causes of change in water balance within the glacial hydrological system as a whole. Further comparison of this with daily maxima and minima of borehole water levels then allows point measurements within the whole system to infer the role of spatially limited subsections of tunnel-conduit and distributed drainage in temporary storage and release of subglacially routed water.

\section{Period I: JD 224-234}

The increasing trend in maximum and minimum daily water levels in borehole 54 from JD 225 to 227 is in-phase with an increase in runoff, water balance and storage (Fig. 6). Despite discontinuous data, water levels in borehole 33 also appear to reflect this increase. Runoff from two rainfall events on JD 228, which are rapidly reflected by the double peak in discharge, intersperse an otherwise low daily total runoff. Subsequently, despite storage continuing to increase, there is a decline in maximum daily water levels in borehole 54 through JD 231. A similar decline in maximum daily water levels can be interpreted from discontinuous data in boreholes 10 and 33 on JD 229 and 230. On JD 231, however, the decline in maximum daily water levels that continues in borehole 54 is reversed in boreholes 10 and 33. Maximum and minimum water levels increase in boreholes 10 and 33 on JD 232 as the trend in cumulative water balance changes from storage to release.

This out-of-phase variation in borehole water levels around the time that storage ends and release starts on JD 232 suggests a difference in the type of subglacial hydrological regime affecting the boreholes. A consistent decrease in water pressure around borehole 54 indicates that, during a period of storage, subglacially routed water is routed away from the borehole. As there is not an immediate accompanying increase in discharge on JD 230, water levels in borehole 54 are likely to reflect local reorganization within distributed drainage as a result of increasing water storage away from tunnel-conduit-style drainage. The decrease in maximum water level in borehole 54 out of phase with boreholes 10 and 33 on JD 232 suggests hydrological connections are made between distributed and tunnel-conduit systems. This allows water in temporary storage to be discharged rapidly through the tunnel-conduit network. Resulting increases in water fluxes (and consequent water pressures) in the tunnel-conduit network are reflected by in-phase increases in water levels in boreholes 10 and 33 . 


\section{Period II: JD 234-241}

As water storage begins to increase on JD 235, maximum daily water levels in borehole 33 on JD 235 increase out of phase with discharge, runoff and water levels in borehole 10 (Fig. 7). The increase in water levels in borehole 33 could be a result of highly localized subglacial water fluxes that are not representative of major fluxes within the whole glacial system, or potentially it could reflect water pressures in expanding areas of distributed drainage that become more local to the borehole.

Increasing daily runoff maxima and minima from JD 235 cause water storage in distributed drainage to increase until JD 238, where low maximum daily runoff causes low pressures in the tunnel-conduit network and low water levels in boreholes 10 and 33. Consequently, the pressure gradient between high water pressures in distributed drainage and low water pressures in the tunnel-conduit system becomes great enough to force hydrological connections between the two systems and release water from temporary storage. Release of water from temporary subglacial storage is particularly evident in the double peak in daily discharge. The second peak in discharge is unrelated to any meteorological event, and therefore is likely to be a direct result of a release in subglacially stored water after an increase in hydrological connectivity in the subglacial hydrological system. The release of water into the tunnel-conduit system that causes a second peak in discharge is also evident as an abrupt change in gradient in the declining diurnal limb of water levels in borehole 10. This provides further evidence for hydrological connectivity between water levels in borehole 10 and water fluxes through tunnel-conduit drainage.

\section{Period III: JD 245-252}

Reversal of the decreasing trend in water balance on JD 248 to an increasing trend in storage is coincident with a snowfall event, which effectively temporarily shuts off runoff over Findelengletscher on JD 247 and 248 (Fig. 8). Discharge during this period is mostly attributed to the release of water that remains in temporary subglacial storage. Very low maximum daily discharge on JD 247 and a low maximum water level in borehole 10 suggest that water has drained from temporary storage and is no longer available to supplement flow through the tunnel-conduit system. Net effective pressures increase as a result of low channel water pressures during this period, causing a large decrease in the capacity of subglacial channels to discharge subsequent runoff. Decrease in the capacity to discharge will preferentially occur through closure of temporary connections between distributed and tunnel-conduit drainage. At this late stage in the ablation season, however, fragmentation through creep closure of the tunnel-conduit system may also occur. As a result, maximum and minimum daily water levels in borehole 10 increase from JD 248 to 250 , due to increasing volumes of runoff though constricted channels becoming temporarily backed up during the daytime and being discharged at night.

\section{CONCLUSIONS}

Calculations of changes in water balance within the glacial hydrological system from modelled runoff (inputs) and measured proglacial discharge (outputs) provide a quantitative estimate of water fluxes through a temperate glacier.
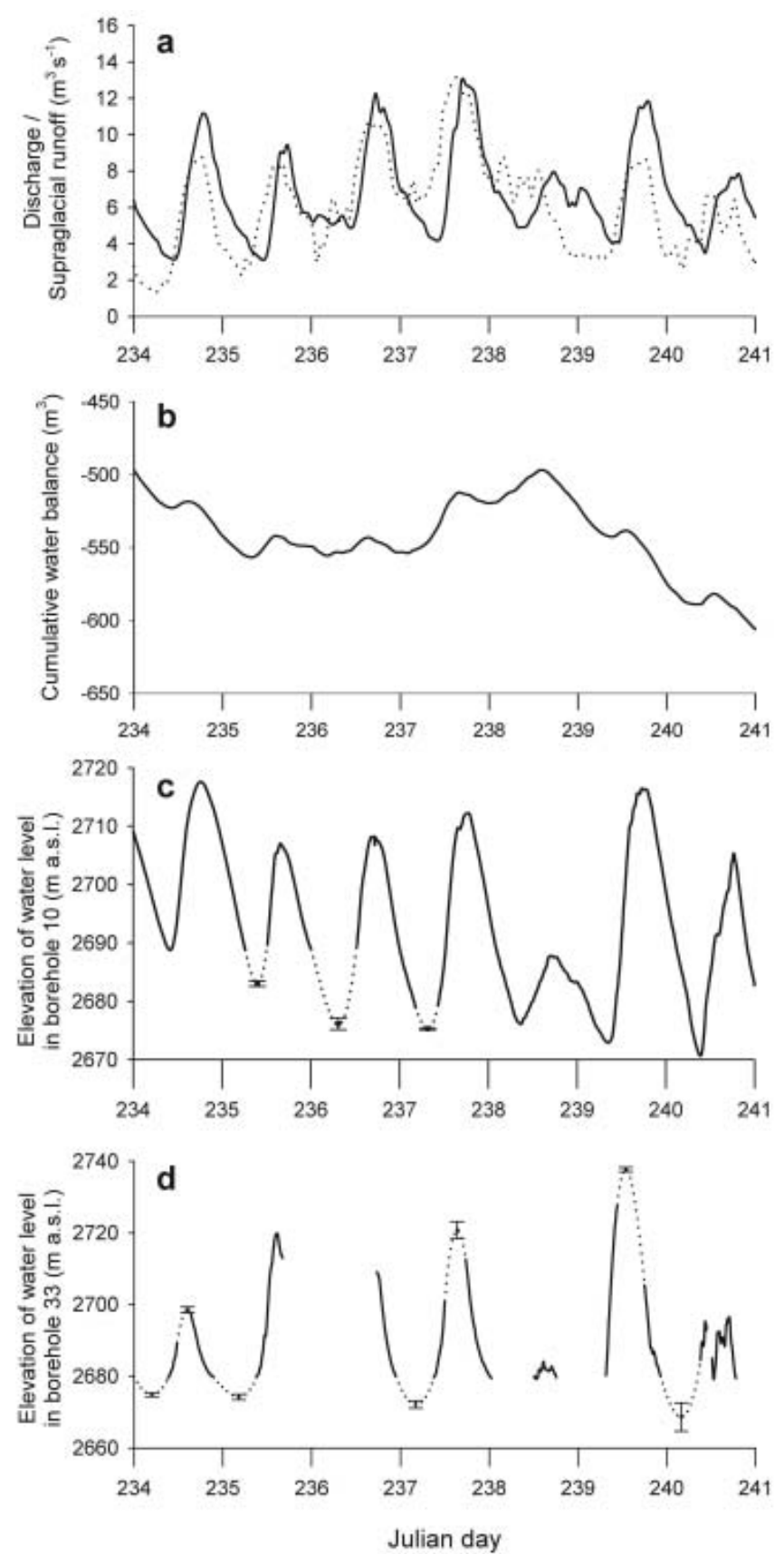

Fig. 7. (a) Surface runoff (pecked line) and proglacial discharge (solid line); (b) cumulative water balance; (c, d) water levels in boreholes 10 (c) and 33 (d). Estimates are made of borehole water levels during periods with missing data (pecked line) including estimates of diurnal maximum and minimum water levels (with error bars at $99 \%$ confidence intervals).

Consequently, the cumulative water balance provides an indication of water storage and release within the glacier. Although underestimates in modelled runoff may also cause absolute volumes in the water balance to be underestimated, timings of the changes between increasing and decreasing cumulative water balance are useful to focus analyses on periods when water accumulates as (or is released from) temporary storage. Analyses of three such periods are conducted using phase relationships between daily maxima, daily minima and diurnal ranges of supraglacial runoff, proglacial discharge and borehole water levels. This provides a quantitative framework for assessing the 


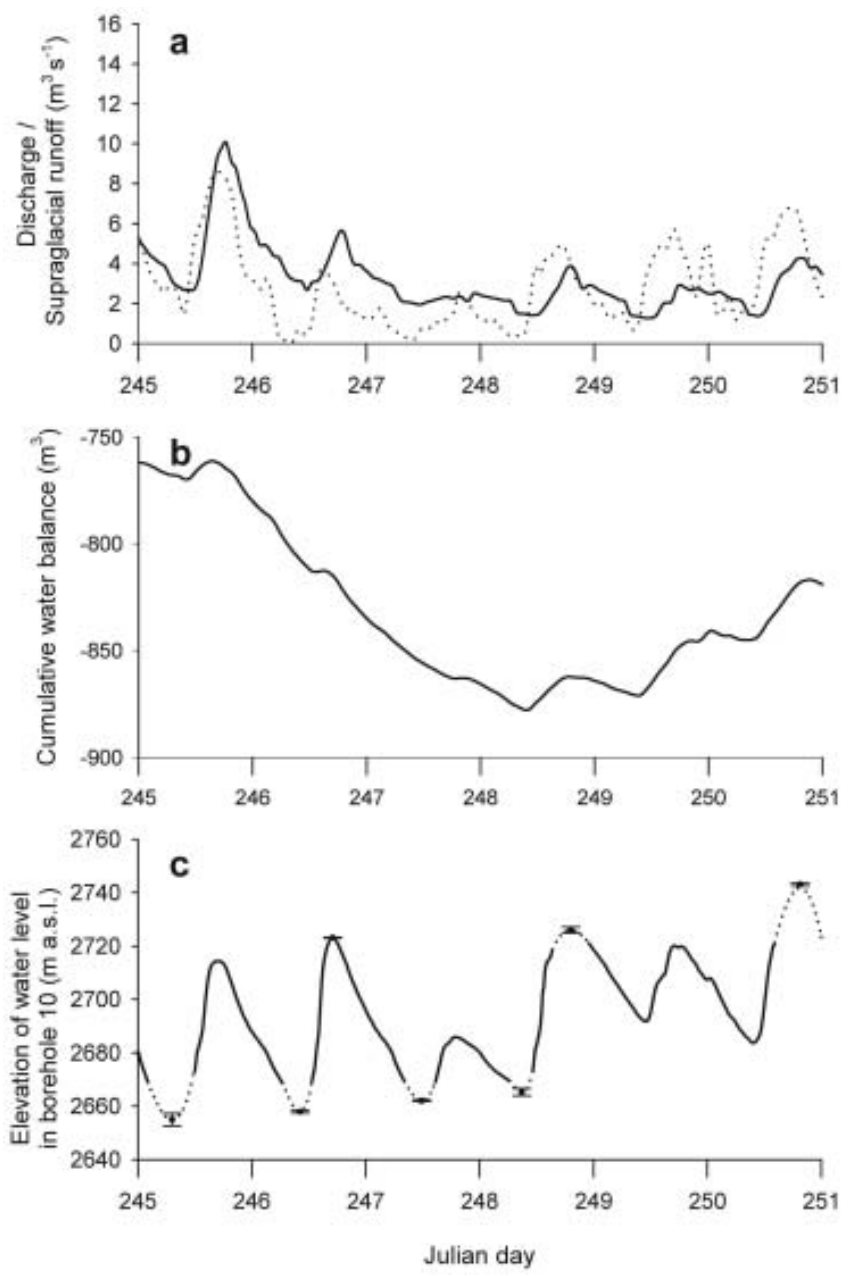

Fig. 8. (a) Surface runoff (pecked line) and proglacial discharge (solid line); (b) cumulative water balance; (c) water levels in borehole 10. Estimates are made of borehole water levels during periods with missing data (pecked line) including estimates of diurnal maximum and minimum water levels (with error bars at $99 \%$ confidence intervals).

impact of hydrometeorological and glaciological factors on subglacial routing of surface runoff.

Variations of water levels in 21 boreholes drilled to the glacier bed suggest that although subglacial drainage is spatially dynamic, hydrologically efficient tunnel-conduitstyle drainage dominates diurnal cycles of water transfer through the glacier. Over longer periods, however, storage and release of subglacially routed water is greatly influenced by the coexistence of hydrologically inefficient distributed drainage with the tunnel-conduit network. During the midablation season, temporary subglacial storage of runoff occurs primarily in areas of distributed drainage. Release of water from temporary subglacial storage is attributed to the formation of hydrological connections between areas of distributed and tunnel-conduit drainage. Connections form when the difference in water pressure between distributed and tunnel-conduit systems causes the hydraulic gradient to exceed localized subglacial stability thresholds at an icebedrock interface or in a sedimentary substrate. During hydrological periods I and II, water storage in distributed drainage increases enough to allow connections to be made to the tunnel-conduit drainage system via this mechanism. It is suggested in period I that hydrological reorganization within distributed drainage concentrates the spatial distribution of water storage and therefore increases the hydraulic gradient sufficiently to connect to the tunnel-conduit system. In period II, release of water from temporary storage is likely to occur as a result of low volumes of runoff causing water pressures in the tunnel-conduit system to decrease. This, in turn, increases the hydraulic gradient with adjacent areas of distributed drainage sufficiently to create the necessary hydrological connections for water flow from distributed drainage.

Hydrological period III illustrates the initiation of water storage towards the end of the ablation season. The combination of water having drained from temporary storage and very low runoff associated with a low-elevation snowfall event is likely to cause low water pressures throughout subglacial drainage. Consequently, hydrological connections both between and within tunnel-conduit and distributed drainage will close and constrict, creating a greater proportion of subsequent runoff to become temporarily stored.

\section{ACKNOWLEDGEMENTS}

Grande Dixence SA provided discharge and air-temperature data from Findelengletscher as well as logistical support in Switzerland. D.N. Collins provided logistical support during fieldwork, and the stimulus for this research problem. A.G.G. Lee and many members of the Alpine Glacier Project from the Universities of Oxford, Manchester and Salford assisted with fieldwork in Switzerland during 1999. The comments of T. Schuler and an anonymous referee helped to improve this paper.

\section{REFERENCES}

Anderson, S.P., K.M.H. Fernald, R.S. Anderson and N.F. Humphrey. 1999. Physical and chemical characterization of a spring flood event, Bench Glacier, Alaska, USA: evidence for water storage. J. Glaciol., 45(150), 177-189.

Anderson, S.P., S.A. Longacre and E.R. Kraal. 2003. Patterns of water chemistry and discharge in the glacier-fed Kennicott River, Alaska: evidence for subglacial water storage cycles. Chemical Geol., 202(3-4), 297-312.

Barrett, A.P. and D.N. Collins. 1997. Interaction between water pressure in the basal drainage system and discharge from an Alpine glacier before and during a rainfall-induced subglacial hydrological event. Ann. Glaciol., 24, 288-292.

Bearth, P. 1953. Map no. 535. Geologischer Atlas der Schweiz. (Scale $1: 25$ 000.) Bern, Swiss Geological Commission.

Bezinge, A. 1987. Glacial meltwater streams, hydrology and sediment transport: the case of Grande Dixence hydroelectricity scheme. In Gurnell, A.M. and M.J. Clark, eds., Glaciofluvial sediment transfer: an Alpine perspective. Chichester, John Wiley and Sons, 473-498.

Cohen, D., R. LeB. Hooke, N.R. Iverson and J. Kohler. 2000. Sliding of ice past an obstacle at Engabreen, Norway. J. Glaciol., 46(155), 599-610.

Collins, D.N. 1982a. Temporal variations of meltwater runoff from an Alpine glacier. In Proceedings of the Symposium on the Hydrology of Research Basins, Bern, Sonderh. Landeshydrologie, 781-789.

Collins, D.N. 1982b. Water storage in an Alpine glacier. In Glen, J.W., ed. International Association of Hydrological Sciences Publication 138 (Symposium at Exeter 1982 - Hydrological Aspects of Alpine and High-Mountain Areas), 113-122.

Collins, D.N. 1998. Outburst and rainfall-induced peak runoff events in highly glacierized Alpine basins. Hydrol. Process., 12(15), 2369-2381. 
Denner, J. and 6 others. 1999. Seasonal variability in hydrologicsystem response to intense rain events, Matanuska Glacier, Alaska, U.S.A. Ann. Glaciol., 28, 267-271.

Fountain, A.G. 1993. Geometry and flow conditions of subglacial water at South Cascade Glacier, Washington State, U.S.A.; an analysis of tracer injections. J. Glaciol., 39(131), 143-156.

Fountain, A.G. 1994. Borehole water-level variations and implications for the subglacial hydraulics of South Cascade Glacier, Washington State, U.S.A. J. Glaciol., 40(135), 293-304.

Gordon, S., M. Sharp, B. Hubbard, C. Smart, B. Ketterling and I. Willis. 1998. Seasonal reorganization of subglacial drainage inferred from measurements in boreholes. Hydrol. Process., 12, 105-133.

Gordon, S. and 7 others. 2001. Borehole drainage and its implications for the investigation of glacier hydrology: experiences from Haut Glacier d'Arolla. Hydrol. Process., 15(5), 797-813.

Hock, R. 1999. A distributed temperature-index ice- and snowmelt model including potential direct solar radiation. J. Glaciol., 45(149), 101-111.

Hodge, S.M. 1979. Direct measurement of basal water pressures: progress and problems. J. Glaciol., 23(89), 309-319.

Hooke, R.L., T. Laumann and J. Kohler. 1990. Subglacial water pressures and the shape of subglacial conduits. J. Glaciol., 36(122), 67-71.

Hubbard, B.P., M.J. Sharp, I.C. Willis, M.K. Nielsen and C.C. Smart. 1995. Borehole water-level variations and the structure of the subglacial hydrological system of Haut Glacier d'Arolla, Valais, Switzerland. J. Glaciol., 41(139), 572-583.

Iken, A. and R.A. Bindschadler. 1986. Combined measurements of subglacial water pressure and surface velocity of Findelengletscher, Switzerland: conclusions about drainage system and sliding mechanism. J. Glaciol., 32(110), 101-119.

Iken, A. and M. Truffer. 1997. The relationship between subglacial water pressure and velocity of Findelengletscher, Switzerland, during its advance and retreat. J. Glaciol., 43(144), 328-338.

Jansson, P., R. Hock and T. Schneider. 2003. The concept of glacier storage: a review. J. Hydrol., 282(1-4), 116-129.

Kamb, B. 1987. Glacier surge mechanism based on linked cavity configuration of the basal water conduit system. J. Geophys. Res., 92(B9), 9083-9100.

Murray, T. and G.K.C. Clarke. 1995. Black-box modeling of the subglacial water system. J. Geophys. Res., 100(B7), 10,23110,245 .

Nash, J.E. and J.V. Sutcliffe. 1970. River flow forecasting through conceptual models. Part 1. A discussion of principles. J. Hydrol., 10(3), 282-290.

Nienow, P., M. Sharp and I. Willis. 1996a. Temporal switching between englacial and subglacial drainage pathways: dye tracer evidence from the Haut Glacier d'Arolla, Switzerland. Geogr. Ann., 78A(1), 51-60.

Nienow, P.W., M.J. Sharp and I.C. Willis. 1996b. Velocitydischarge relationships derived from dye tracer experiments in glacial meltwaters: implications for subglacial flow conditions. Hydrol. Process., 10, 1411-1426.

Østrem, G. and M. Brugman. 1991. Glacier mass-balance measurements: a manual for field and office work. Saskatoon, Sask., Environment Canada. National Hydrology Research Institute.

Röthlisberger, H. 1972. Water pressure in intra- and subglacial channels. J. Glaciol., 11(62), 177-203.

Rutter, N.J. 2002. Subglacial water storage in an Alpine glacier. (PhD thesis, University of Oxford.)

Schneider, T. 2000. Hydrological processes in the wet-snow zone of glaciers - a review. Z. Gletscherkd. Glazialgeol., 36(1), 89-105.

Schneider, T. 2001. Hydrological processes in firn in Storglaciären, Sweden. (PhD thesis, Stockholm University.)

Schuler, T., U.H. Fischer, R. Sterr, R. Hock and G.H. Gudmundsson. 2002. Comparison of modeled water input and measured discharge prior to a release event: Unteraargletscher, Bernese Alps, Switzerland. Nord. Hydrol., 33(1), 27-46.

Schuler, T., U.H. Fischer and G.H. Gudmundsson. 2004. Diurnal variability of subglacial drainage conditions as revealed by tracer experiments. J. Geophys. Res., 109(F2) F02008. (10.1029/ 2003JF000082.)

Smart, C.C. and D.B. Ketterling. 1997. A low-cost electrical conductivity profiler for glacier boreholes. J. Glaciol., 43(144), 365-369.

Stone, D.B. and G.K.C. Clarke. 1996. In situ measurements of basal water quality and pressure as an indicator of the character of subglacial drainage systems. Hydrol. Process., 10(4), 615-628.

Süsstrunk, A.E. 1959. Rapport sur les sondages sismiques du Glacier de Findelen effectués en Octobre 1959. Lausanne, Grande Dixence SA.

Walder, J.S. and A. Fowler. 1994. Channelized subglacial drainage over a deformable bed. J. Glaciol., 40(134), 3-15.

\section{APPENDIX \\ RECONSTRUCTION OF MISSING BOREHOLE WATER-LEVEL DATA}

When there are missing data around diurnal maxima or minima of a borehole water-level time series, if the period of missing data is 12 hours or less, estimates are made of the timing and magnitude of missing maximum or minimum data points. A cubic function is used to fit a regression curve through a maximum of 20 data points, 10 either side of the missing data, using a least-squares method to obtain the best fit. Maximum or minimum values within the periods of missing data are located on the regression curve by differentiating and solving the cubic regression equation to find the stationary points.

Estimated uncertainty in maximum or minimum water levels is calculated by assuming that the set of 20 observed data points act as a sample from a normally distributed population. This sample can then be represented by a Student's $t$ distribution, which is used as a probability density function to help establish confidence limits. Using standard statistical tables, at 19 degrees of freedom, 99\% of the population lie between 2.539 standard deviations of the mean. Consequently, the upper limit (or potential error) of a missing maximum value is calculated by subtracting the product of 2.539 and the standard deviation from the first and last 5 observed data points of the 20 surrounding the period of missing data. The middle 10 observed data points of the 20 are raised by the same amount. A cubic regression curve is then fitted to these new data, and the stationary point is solved to find the upper $99 \%$ confidence limit around the diurnal maximum. The lower 99\% confidence limit around the diurnal maximum is calculated in the same manner, but instead by raising the first and last 5 observed data points by the same product and lowering the middle 10 data points.

To check the appropriateness of the method used to estimate missing data, artificial gaps were made in continuous datasets, and actual maxima or minima were compared with reconstructed maxima or minima found using the method outlined above. Gaps in continuous data were created of random duration between 3 and 12 hours in 15 complete maxima or minima. The mean absolute percentage error between actual and reconstructed maxima or minima is $2.0 \%$, which suggests that a cubic function is appropriate for reconstruction of missing data. 